\title{
Conservation status of the rare endemic Centaurium tenuiflorum subsp. anglicum, English Centaury (Gentianaceae)
}

\author{
Elizabeth L. Downey ${ }^{1}$, David A. Pearman², Timothy C.G. Rich ${ }^{3 *}$ \\ ${ }^{1}$ Wadeford, U.K., ${ }^{2}$ Truro, U.K., ${ }^{3}$ Cardiff, U.K.
}

*Corresponding author: Timothy C.G. Rich: tim rich@sky.com

This pdf constitutes the Version of Record published on $26^{\text {th }}$ July 2021

\begin{abstract}
The status of the rare English endemic Centaurium tenuiflorum subsp. anglicum, English Centaury, has been assessed from field surveys in 2020 and compared against previous population counts. In Dorset, 16 populations with $c .25,815$ plants occurred and there was no evidence of overall decline. It was not refound in one site in the Isle of Wight. The IUCN threat status is 'Least Concern'.
\end{abstract}

Keywords: England; IUCN threat status; Dorset; Isle of Wight

\section{Introduction}

Centaurium tenuiflorum subsp. anglicum T.C.G. Rich \& McVeigh, English Centaury (Gentianaceae) is a rare endemic known from about 18 sites in v.c.9 (Dorset) and v.c.10 (Isle of Wight) in Southern England (Rich et al., 2019; Rich \& McVeigh, 2019; Figs. 1-3). A short video describing the plant and its habitats is given by Rich (2020).

The JNCC (2020) assessment of its IUCN (2001) threat status as 'Least Concern' was based on 1996-2002 data in Edwards \& Pearman (2004). In 2020, all accessible populations were revisited to obtain up-to-date population counts. The aim of this short paper is to present the data and update the threat status.

\section{Methods}

In Dorset the entire coastline between St Gabriels and West Bay was checked from the base of the cliffs by E. Downey; no populations occur on the cliff tops. Each population was counted as far as practical on the steep slopes, mapped with GPS and photographed. The larger populations tend to be somewhat fragmented and the counts are summations of the sub-populations. The populations were correlated against the sites in Edwards \& Pearman (2004), some of whose 1996 grid references were estimated from maps rather than with a GPS. Full details are held by the authors and are available on request for bona fide researchers. On the Isle of Wight, the Medina Estuary, the only publicly-accessible site, was visited by T.C.G. Rich; no access was available to the King's Quay site. 2013).

Estimates of extent of occupancy were calculated using MAGIC maps (DEFRA, 


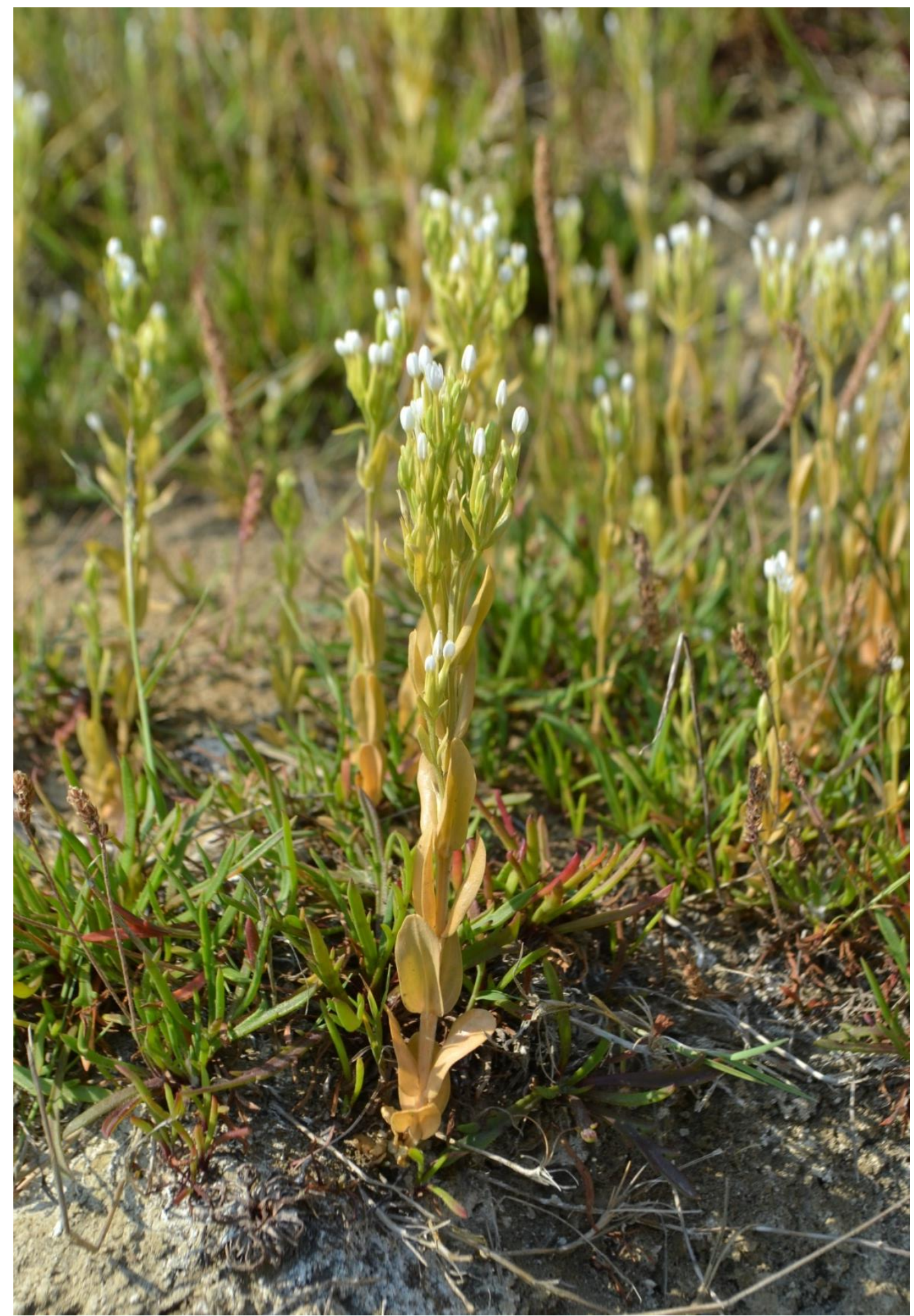

Figure 1. Centaurium tenuiflorum subsp. anglicum, Eype. Photo T.C.G. Rich 2018.

\section{Results}

The counts from 2020 are summarised below with the equivalent 1996 or 2002 counts from Edwards \& Pearman (2004).

Broom Cliff, St Gabriels SY392923

On 9 August 2020, five small plants were found growing amongst sparse vegetation. 


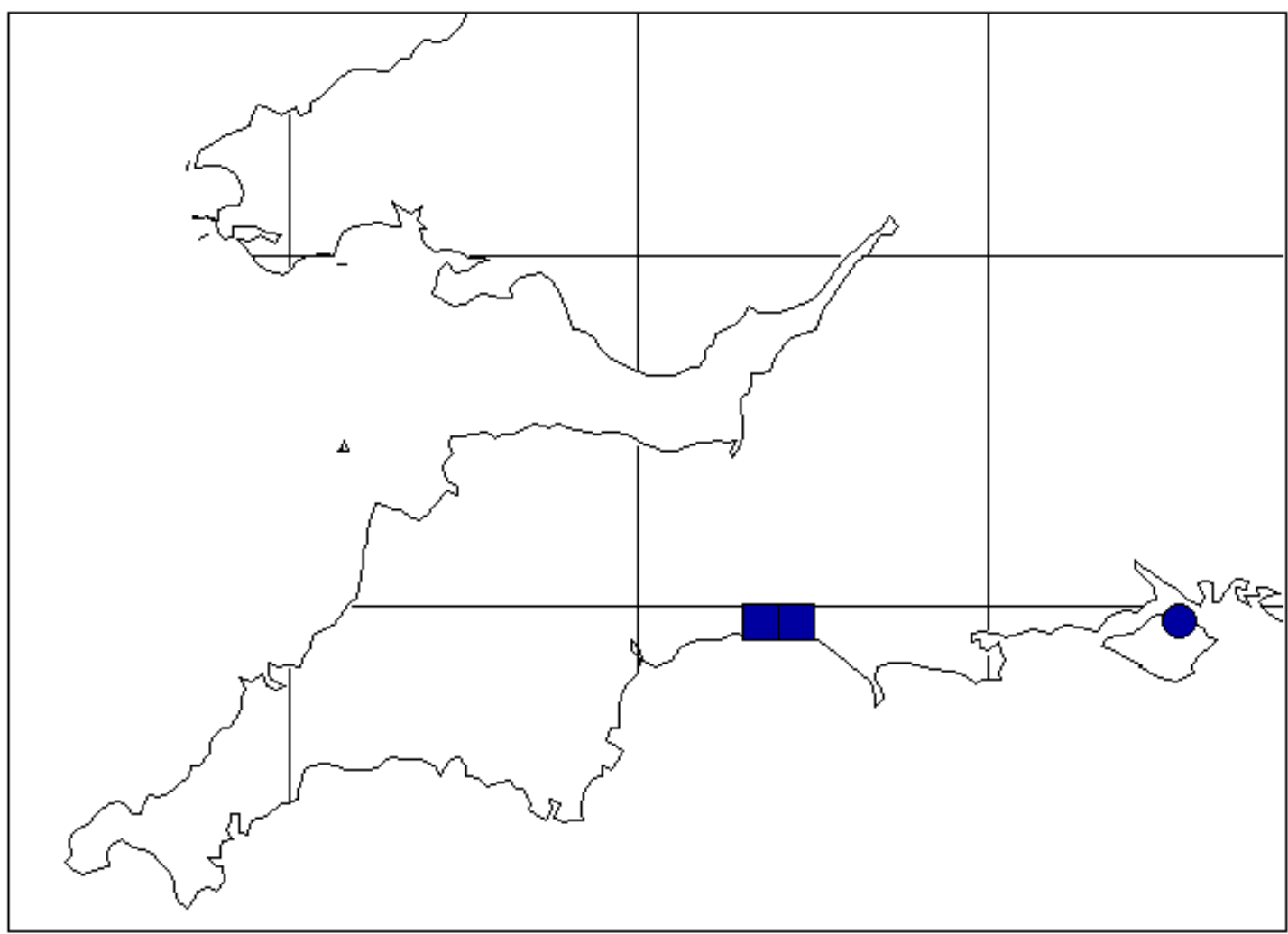

Figure 2. Distribution of Centaurium tenuiflorum subsp. anglicum in hectads in southern England. $\square$ 2020. • Pre-2020.

St Gabriels SY398922

In 2002, c.5000 plants occurred in a large open area of cliff, over $35 \mathrm{~m}$ above the beach, extending over $150 \mathrm{~m}$. In 2020, no plants were found and the cliffs looked quite overgrown.

Golden Cap (west) SY401920

In 2002, c.5000 plants occurred. On 5 August 2020, 2275 plants were found on a steep slump which was mostly being grown over by other plants such as Phragmites australis.

Golden Cap (east) SY407918

In 1996, 650 plants occurred. On 8 August 2020, 7930 plants were found over large area of the flat slump at the base, both on bare ground and among Phragmites.

Seatown (west) SY415918

In 1996, 300 plants occurred. On 8 August 2020, five plants were found growing among sparse vegetation towards the top of the cliff.

Seatown (east) SY422915

In 1996, 350 plants occurred. On 29 July 2020, 100 plants were found among sparse vegetation on a cliff slump. 

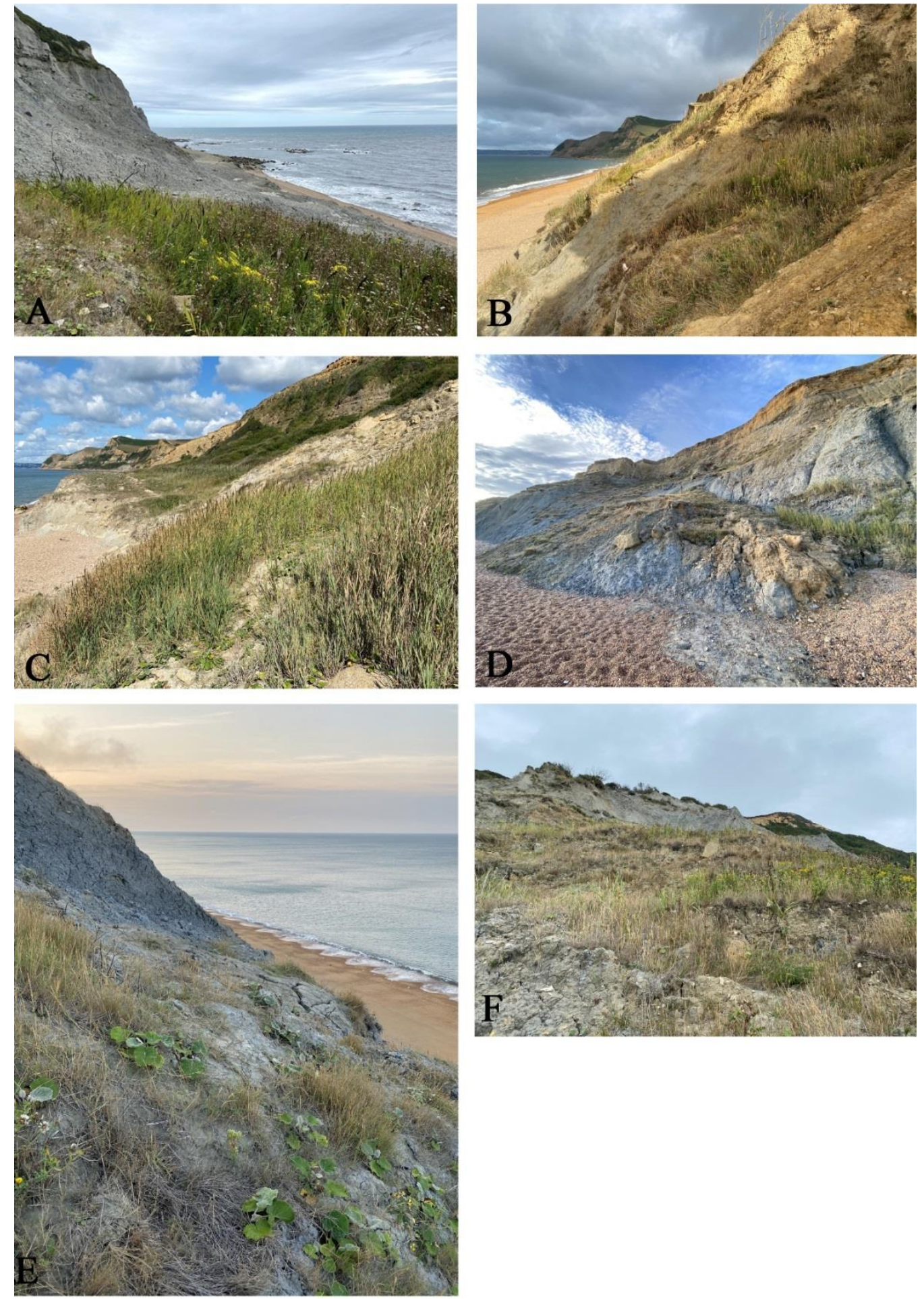

Figure 3. Habitats of Centaurium tenuiflorum subsp. anglicum. A. Typical habitat of west locations from Broom Cliff to Golden Cap on slumps of dry, grey clay. B. Habitat typical of Eype populations on drier, more stable brown clay. C. West Cliff - growing in reeds and stretching up the bare slope behind. D. Seatown (east). E. Steeper and more unstable grey cliffs either side of Seatown. F. Golden Cap slopes. Photos E. Downey 2020. 
Ridge Cliff, Seatown SY427912

In 1996, 20 plants occurred. On 29 July 2020, 100 plants were found on unstable ground on the edge of a cliff slump.

Dog House Hill (Thorncombe Beacon A) SY431913

On 30 July 2020, 2550 plants were found amongst sparse vegetation on the edge of a cliff slump.

\section{Thorncombe Beacon SY432913}

In 1996, 289 plants occurred. On 30 July 2020, 110 plants were found growing among Phragmites at the base of the cliff.

Thorncombe Beacon (east) SY441912

In 1996, 230 plants occurred. No plants were found in 2020.

\section{Eype (west A) SY442912}

In 1996,250 plants occurred. On 28 July 2020, one plant was found growing among vegetation on an unstable slump.

Eype (west B) SY44311

On 28 July 2020, five plants were found growing amongst vegetation on the edge of a slump.

Eype (west) SY445911

In 1996, 1258 plants occurred. No plants were found in 2020.

Eype (west C) SY446910

In 1996, 108 plants occurred. On 2 August 2020, 90 plants were found growing among Phragmites and on bare clay.

Eype car park SY447910

On 2 August 2020, 5670 plants were found growing on cliff slopes below the car park, some of which were trampled.

Eype (east A) SY448909

On 3 August 2020, 1876 plants of varied height were found growing over $c .20 \mathrm{~m}$ length at the edge of a cliff slump.

Eype (east B) SY449909

On 3 August 2020, 768 plants of varied height were found growing over $c .10 \mathrm{~m}$ length at the edge of a cliff slump.

Eype (east C) $5 Y 450909$

On 3 August 2020, 890 mostly small plants were found over $c .15 \mathrm{~m}$ length at the edge of a slump. 
West Cliff SY451908

In 2002, c.1000 plants occurred. On 3 August 2020, 3440 plants, mostly small, were found on dry, bare ground with some among Phragmites on a fairly steep slope.

Medina Estuary SZ502939

No plants were found on the Medina estuary on 16 July 2020; the site has changed since it was last recorded in 2006.

\section{Discussion}

The Dorset populations were estimated to contain $c .14,455$ plants in 15 sites in 1996/2002 (Edwards \& Pearman, 2004). In 2020, c.25,815 plants were found in 16 sites. There is no evidence of decline overall though individual colonies may have increased or decreased, the metapopulation dynamics related to the mosaic of cliff slumps where, following a slip, the plants colonise after 3-4 years and persist until the habitat closes over again (Pearman, 1999). The populations are spread out in a narrow coastal strip perhaps $100 \mathrm{~m}$ wide over about $6 \mathrm{~km}$ of coast. In contrast, no populations are currently known in the Isle of Wight, though one site could not be checked.

Under the IUCN (2001) criteria, the threat status is confirmed as 'Least Concern' despite the severe decline in the 'extent of occupancy' from c.490 km² to $<0.6 \mathrm{~km}^{2}$ due to loss of the Isle of Wight sites, as there are 16 populations with 25,815 plants and no evidence of on-going decline. Most of the populations are on land owned by the National Trust and are statutorily protected as part of the West Dorset Coast SSSI.

\section{Acknowledgement}

We thank Colin Pope and Paul Stanley for help with the Isle of Wight sites. The map was plotted using DMAPW by Alan Morton.

\section{References}

Edwards, B. \& Pearman, D. 2004. Dorset rare plant register. May 2004. Dorchester: Dorset Environmental Records Centre.

IUCN. 2001. IUCN Red list categories and criteria. Version 3.1. Gland: International Union for Conservation of Nature.

JNCC. 2020. Conservation Designations Spreadsheet. http://jncc.defra.gov.uk/page3408 (accessed 26/1/21).

DEFRA. 2013. MAGIC [online] [Accessed January 2021] Available at: https://magic.defra.gov.uk/

Pearman, D.A. 1999. Centaurium tenuiflorum (Hoffsgg. \& Link) Fritsch. In: Wigginton, M. J., ed. 1999. British Red data Books. 1 Vascular Plants. $3^{\text {rd }}$ ed. p. 88. Peterborough: Joint Nature Conservation Committee.

Rich, T.C.G. 2020. English Centaury identification. 'Tim's botanical riches' YouTube Channel [online]. Available at: https://youtu.be/N-UBAaRFAsw

Rich, T.C.G., McVeigh, A. \& Stace, C.A. 2018. New taxa and new combinations in the British flora. Edinburgh Journal of Botany 76: 173-180. doi: $10.1017 /$ S0960428618000288. 
Rich, T.C.G. \& McVeigh, A. 2019. Gentians of Britain and Ireland. BSBI Handbook No. 19. Harpenden: Botanical Society of Britain and Ireland.

Copyright retained by author(s). Published by BSBI under the terms of the Creative Commons Attribution 4.0 International Public License.

ISSN: $2632-4970$

https://doi.org/10.33928/bib.2021.03.161 